\title{
Media and Information Literacy in Inclusive Education: A Team Teaching Concept at the Technische Universität Dortmund
}

\author{
Ingo Bosse, Gudrun Marci-Boehncke \\ Technische Universität Dortmund, Dortmund, Germany
}

There is a desideratum in the research about the interdependencies of inclusive education and media education. Digital media can facilitate individualized and cooperative learning. Additionally, digital media can be used to promote inclusion. However, which factors influence the acquisition of media and information literacy in inclusive education? Comparative international studies, e.g., the International Computer and Information Literacy Study (ICILS), show how social challenges, such as participation and handling heterogeneity at school, can be addressed through media. In numerous studies, it becomes apparent that German teachers do not sufficiently see the potential of digital media, especially for the improvement of learning opportunities for individuals with diverse learning requirements. German teachers are not well able to apply digital media appropriately in their lessons. Teachers need to be qualified and to design modern education with accessible media. In Germany, the ratio between available computers and pupils (1:4) is far better than the rate between teaching with and without computers. According to the teacher's reports, only $9 \%$ of teachers are using digital media daily. Approximately $40 \%$ use digital media seldom or never. It seems that the cause is a skeptical attitude towards media among teachers, especially in humanities. That may result from missing didactical competences regarding digital media. The idea of Technical Pedagogical Content Knowledge (TPACK) and extending that explanatory model for teachers' competencies on the inclusive practices builds the theoretical background for the design of joint seminars by the Research Center Youth-Media-Education as part of the Faculty for Cultural Studies and the Research Cluster Technology for Inclusion and Participation at the University of Dortmund. Prospective teachers should become familiar with this way of collaboration. Already for four years now, a teaching team from these two departments designs collaborative lectures. Inclusive teaching and learning in different contexts are practiced in tutorials with practical approaches as well. In tandems, the students develop a learning situation at school or extracurricular institutions. Afterward, they present it. The presentation focuses on the concept, its teaching and learning conditions, and competence orientation as well as opportunities and limitations.

Keywords: media and information literacy, inclusive education, media education, team teaching, digital scholarship, teachers' education, mediatization

Ingo Bosse, Prof., Dr., Technische Universität Dortmund, Dortmund, Germany.

Gudrun Marci-Boehncke, Prof., Dr., Technische Universität Dortmund, Dortmund, Germany. 


\section{Introduction}

The metatheory of mediatization (Krotz, 2007) justifies the educational policy necessity of considering digital learning environments in schools and universities—not facultatively, but compulsorily. "Empowerment of people through Media and Information Literacy (MIL) is an important prerequisite for fostering equitable access to information and knowledge and promoting free, independent and pluralistic media and information systems" (UNESCO, 2018, n.p.).

Just like mediatization, inclusive education has a disruptive character (Christensen, 1997) in the international education system. With the adoption of the United Nations Convention on the Rights of Persons with Disabilities (UN CRPD) in 2006, which has since been ratified by 177 states (UN, 2006), inclusive education has once again become the focus of international attention and has led to intensive changes in the education systems of numerous countries. Germany belongs to the countries that signed the UN CRPD, but service development in the federal states of Germany is diverse. Each state (i.e., administrative region) has autonomous legislative responsibility, including individual legislation according to the guidelines of the Basic Law system, i.e., the predominant responsibility of the federal states for education. Although all the states adopted the decision on inclusive education of students with disabilities in schools, the current situation is diverse (European Agency for Special Needs and Inclusive Education, 2018): In some states, like Bremen decreased the rate of exclusive education from 2008/09 (4.6\%) to 2016/17 (1.2\%) whereas, in other states, like Bavaria, the rate even increased from 2008/09 (4.6\%) to 2016/17 (4.8\%) (Klemm, 2018, p. 11).

In the European knowledge societies and beyond, media literacy is assigned an even more growing role as a precondition for "full and effective participation in contemporary societies" (del Mar Grandío, Dilli, \& O’Neill, 2017, p. 116). "Full and effective inclusion and participation in society” (UN, 2006, p. 2) is also the ultimate goal of the United Nations Convention on the Rights of Persons with Disabilities.

However, before deepening the description of the parallelity of the discourses on media education and inclusion, the underlying understandings of the central concepts should first be briefly outlined: First of all, the concept of media education needs to be clarified. This article follows the understanding of the term media education as first described internationally in 1982 in the Grünwald Declaration: "During that thirty-year period, media education augmented media and education literacy as a composite notion to take into account both the mediatization and the digitization of the world, in knowledge societies powered by information cultures" (Frau-Meigs, Velez, \& Flores Michel, 2017, p. 1). Thus, the use of the term "Information and Media Literacy" also follows the discourse of media education and not the discourse shaped by the international library networks, although these cannot always be separated. It follows UNESCO's understanding of media and information literacy:

Media and Information Literacy recognizes the primary role of information and media in our everyday lives. (...) it empowers citizens to understand the functions of media and other information providers, to critically evaluate their content, and to make informed decisions as users and producer of information and media content. (...) A particular focus will be on training teachers to sensitize them to the importance of MIL in the education process, enable them to integrate MIL into their teaching and provide them with appropriate pedagogical methods, curricula, and resources. (UNESCO, 2017, n.p.)

The terminological diversity that can be found in research about the discourse on media competence, digital competence, and digital literacy was recently (McGarr \& McDonagh, 2019, pp. 6-11) examined more closely in the context of the DiCTE study. In addition to national differences, which the authors cite as an 
explanation of diversity, disciplinary differences also seem to be relevant. The reference sciences for a discussion about the successful handling of media in general and digital media, in particular, are numerous. The authors of the article here represent the rehabilitation sciences with reference to pedagogy, on the one hand, and German studies with reference to library sciences, media sciences, and pedagogy as well as reading promotion on the other hand. After decades of debates on the demarcation between general pedagogy, educational science, media studies, and didactics about such terminological differences, we have decided to operate for our cooperation with a broad common understanding. That is pragmatically aimed at enabling pupils to use all media that are and will be available to society to their satisfaction and equal participation in society in a safe, sovereign, responsible, reflective, creative, convergent, and participatory manner.

In media education, as in school education as a whole, it is essential to do justice to all children and young people with all diversity dimensions in their complexity and their various combinations (Abels \& Schütz, 2016). Just like the metatheory of mediatization, the metatheory of inclusion describes a fundamental social change (Marci-Boehncke \& Bosse, 2018). For media education, the associated perspectives of the further development of society, as Kronauer (2013) described them, are more significant than the view of the living conditions and relationships of individual social groups, such as people with disabilities (Zorn, Schluchter, \& Bosse, 2019).

Inclusive education is a process of strengthening the capacity of the education system to reach out to all learners, and one can thus understand it as a key strategy to achieve EFA. (...) Education for All must take account of the needs of the poor and the disadvantaged, including working children, remote rural dwellers and nomads, ethnic and linguistic minorities, children, young people and adults affected by conflict, HIV and AIDS, hunger and poor health, and those with disabilities or special learning needs. (UNESCO, 2009, p. 8)

Although following this broad understanding of inclusion, the dimension of disability is particularly focused, since the presented seminar concept deals with the joint training of general teachers and teachers for special educational advancement.

The subject of German occupies a unique position in the canon of subjects in Germany, since the media are not only teaching materials but also the subject of instruction. Already in the Grünwald Declaration, the particular position of language teaching was emphasized: "Such a reassessment might well result in an integrated approach to the teaching of language and communication” (Grünwald Declaration, 1982, n.p.). For inclusive education, digital media in Germany offer ideal opportunities not only through technical assistance but also given their convergent work opportunities (Jenkins \& Kelley, 2013; Marci-Boehncke, 2018). Media convergence refers to cross-media action. Content can be presented in different media, the media industry acts convergent when different media work together, and the media audience turns to this content depending on how it is presented (Thiele \& Bosse, 2019).

This article presents a scientifically evaluated teaching concept on inclusive media education. In two seminars per semester, students of teaching professions at the TU Dortmund are trained in German for various diagnostic, promotional and creative uses of digital media.

\section{Contextual Factors for the Acquisition of Media and Information Literacy in Inclusive Education}

This article refers to the theory of mediatization (Krotz, 2007) and its consideration in educational institutions (such as schools and universities) and society (political decision-making level). In the context of inclusive teaching/learning contexts, mediatization then plays a dual role: On the one hand, it is of interest, to 
what extent teachers are aware of the media conditions and possibilities for the action of pupils with special teaching/learning prerequisites (Bosse, 2018). On the other hand, one can ask to what extent they could use technological aids and didactic possibilities for a variation to create more accessible opportunities for participation for this clientele of pupils (Marci-Boehncke, 2018). Another condition for success that teaching development research has identified as central to inclusive subject didactics is "the targeted and conscious use of highly differentiated teaching and learning materials” (Wember, 2013, p. 380). Besides, the cooperation and joint design of teaching by teachers from different training backgrounds, such as subject teachers and teachers for special educational support seem to be highly valuable and a desideratum in German teachers education (Richter \& Pant, 2016).

\section{Mediatization and University Teacher Training}

Mediatization is a meta-process that attempts to describe the changes in society in the context of its contemporary mediality. Mediatization has always existed and occurred in (much discussed and criticized) "thrusts": Book printing (15th century), newspaper debate (16th \& 17th century), novel reading (18th century), dirt and trash debate (19th \& 20th century), current PC, games, Internet. Krotz further developed Uri Bronfenbrenner's (1981) ecosystemic approach, which dates back to the 1960s, and on the other hand, combines it with various communication models. According to Krotz, mediatization takes place at the level of micro social relations (person to person), at the level of institutional relations (students to universities, teachers, and learners to schools. With a view to a particular school, its mission statement, its equipment, its internal curriculum, its cooperation, proximity to libraries), and the macro system (society as a whole, curriculum, media politics, and technical development). Recently, the attitudes of teachers towards digital media have also been rediscovered as an influential factor (Lorenz, Endberg, \& Eickelmann, 2017a, pp. 114-118). They include epistemological beliefs, worldviews, and attitudes that are both rational and irrational. They are a product of general and, of course, school socialization and are considered difficult to change. According to Baumert and Kunter (2006), the existing studies on this subject are also more about "intuitive theories” which are intended to influence thinking, reasoning, information processing, learning, and motivation (Köller, Baumert, \& Neubrand, 2000), i.e., are themselves oriented more towards pedagogical issues and less to domain-specific, specialist scientific background. Based on the theory of mediatization, the present teaching/learning model was developed and evaluated at the TU Dortmund.

The Technical Pedagogical Content Knowledge (TPACK) Model (Shulman, 1986; Koehler \& Mishra, 2005) served as a model for this. It can be used to examine the question of how teachers integrate media and technology into teaching/learning processes, what skills they need, and how well trained they feel they are (Scherer, Tondeur, \& Siddiq, 2017). TPACK differentiates between the domains general knowledge, content knowledge, pedagogical knowledge, subject didactic knowledge, and the technological domain. In the meantime, several studies have been carried out to check the validity of the domains (e.g., Scherer et al., 2017). They allow the statement that TPACK is a suitable model for both researchers and teachers to describe competencies and skills that are necessary for the effective integration of information and communication technologies (Scherer et al., 2017, p. 2). If one expands the TPACK Model towards the topic of inclusion, additional intersections, and a kind of super core arise-the Inclusion-Technological Pedagogical Content Knowledge (I-TPACK). Depending on the starting point from which one views the fields of competence, one detects new cross-sectional professionalization (Marci-Boehncke, 2018, p. 58). 


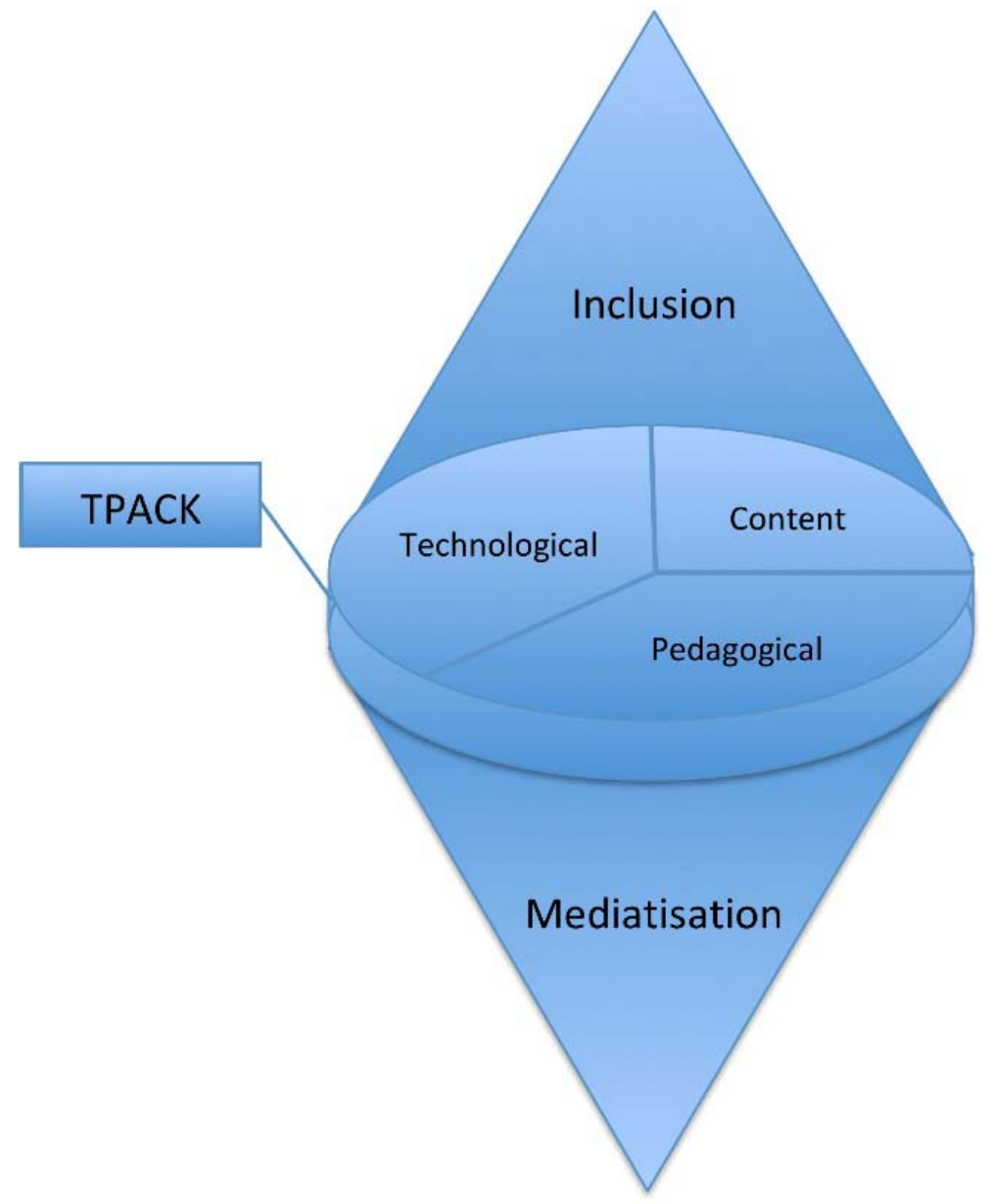

Figure 1. Model I-TPACK (Source: Marci-Boehncke, 2018, p. 58).

This model is mainly suitable for explaining and planning new aspects of competence in training. As a research perspective, we wanted to find out whether students show further changes in attitudes and self-assessed competencies. Long-term studies, which ask students about their practical experience beyond their degree, are also desirable to gain an impression of how long such disruptive theories take to be anchored in teacher training in Germany and what role reflection on theoretical knowledge and practical experience play in this.

Comparative school research has identified a lack of didactic and methodological competence as a decisive inhibitor for teachers to integrate new technologies into teaching and learning processes. In this context, suitable further training courses and inter-school teacher cooperation offer starting points for targeted teacher professionalization measures. An international comparison shows that, on average, teachers in Germany rarely participate in advanced training courses on the use of digital media and that teacher cooperation often takes place at a simple exchange-of-materials level (Bos et al., 2016). Similarly, the success and use of assistive technologies depend directly on the methodological competencies and knowledge of teachers, which in turn relate to the methods experienced by teachers in the context of their university education (Thiele, 2016, pp. 317-318). Self-efficacy experiences, flexibility, and confidence in action are-besides technical resources-regarded as the most important individual characteristics for the integration of digitality in the 
teaching/learning context. Desiderates exist in a competent digital system administration and co-constructive cooperation between teachers, especially in the context of inclusion between special education and subject teachers. The acquisition of didactic, pedagogical, and technical skills should already take place during the training of all teachers. The prerequisite for this is an appropriate technical and personnel infrastructure in schools.

\section{Co-teaching at Inclusive Schools}

Authors from countries with a long tradition of inclusive schooling describe co-teaching as a "prerequisite and guarantor for a school for all” (Johnson, 2015). Successful cooperation is an essential success factor for the implementation of school inclusion (Lütje-Klose, 2011; Moser \& Demmer-Diekmann, 2012; UNESCO, 2018). Co-teaching requires mutual understanding and flexible support (European Agency for Special Needs and Inclusive Education, 2003). Co-teaching can be structured as cooperation with specialists of other professions, e.g., therapists, as consultation of specialists of a school or as co-teaching between two regular teachers. Due to its importance, we will examine co-teaching in more detail at this point.

Co-teaching offers the advantage that pupils with different learning requirements and different needs can gain access to the everyday learning object by making differentiated learning offers. Higher student achievement reflects the opportunity to learn from each other (Johnson, 2015). However, this is only the case if co-teaching provides high quality. High-quality co-teaching can be characterized as: adequate training and preparation of the teachers, shared preparation time, codetermination during partner selection, planning time, adequate administrative support, appropriate training opportunities, etc. (Villa, Thousand, \& Nevin, 2004). Co-teaching does not only benefit pupils. More opportunities for professional development and much interdisciplinary cooperation lead to higher professional satisfaction as demonstrated by Mastropieri et al. (2005, as cited in Johnson, 2015). The cooperation enables teachers to expand their skills and abilities (Bešić, Paleczek, Krammer, \& Gasteiger-Klicpera, 2017). For the second training phase of German teachers, which takes place at seminars and schools, there are binding guidelines for the acquisition of competences for co-teaching (Ministry for Schools and Continuing Education of North Rhine-Westphalia, 2016).

Thus, in the first phase of teacher training at university, opportunities for co-teaching experiences should be offered. That is where the hereafter presented teaching, and research concept comes in.

\section{The Teaching and Research Concept “Inclusive Digital Media Education”}

The cooperative teaching and research concept "Inclusive Digital Media Education" is based on the outlined theoretical basis on inclusion and mediatization. Co-teaching-as data by the states monitor about education show (Lorenz et al., 2017b, pp. 96-97)—is not common practice in German schools. All the more reason, therefore, to offer role models here at universities as well. For the particular study practice, this means: Students receive theoretical backgrounds and methodical competencies from two persons. Lecturers from the subjects of German Literacy Didactics and Special Needs Education act in tandem in an exemplary manner in team teaching (e.g., Lütje-Klose, 2011). To ensure a lasting impact on later everyday working life, the combination with practical experiences in inclusive digital media education is of the highest importance (Kontovourki et al., 2017). If students are exemplified here as successful in teaching and teaching together with digital media, the probability increases that they acquire a correspondingly affine habitus (Biermann, 2009).

The intensive, jointly organized exercise situations enable students to experience self-efficacy already during 
their training, thus increasing their flexibility.

\section{Conception and Structure}

The model pursues goals on different professional, didactic, technical, pedagogical, and consciousness-oriented levels, which themselves become clear as cross-sectional competences. Within the framework of teacher training, practical training is of particular importance for the acquisition of skills in teaching inclusive information and media literacy. Students get the opportunity to test the planned teaching settings in the context of school. The students can make teaching/learning experiences in a protected space against the background of the developed theoretical concepts.

On the one hand, the university is establishing a sustainable offer for digital-media work, and the schools are receiving suggestions for school development through technical assistance and didactic ideas from the students. The accompanying evaluation process of this research and intervention project, which is based on a triangulation of data, research, and methods (Treumann, 2017, pp. 265-266), surveys the attitudes of students during the seminar as well as those of a selection of teachers from the participating schools. The comprehensive cooperation of inclusive and special needs education and literary didactics allows the interlinking of awareness-raising among school and university actors concerning both inclusion and digitality as current guiding principles of professional teacher action.

The students acquire:

- Competencies in co-teaching by working with professionals from school and the university. Specifically, they chose the co-teaching model. That means that both teachers teach the class together throughout. They alternately or simultaneously become the class leader and keep the current group processes in view (Lütje-Klose, 2011, p. 15). That can mean, for example, while one teacher explains something, the other visualizes the facts medially. With this sophisticated co-teaching model, we focus on the acquisition of critical competencies in inclusion and media education in the form of action competences by learning to cooperate in teams. A joint teaching-learning platform enables corporate communication and works across hierarchies (Jenkins \& Kelly, 2013).

- Media competence in the context of active media work: Learning arrangements with digital media must always be integrated into pedagogical and didactic questions. The "active engagement with the media offers essential opportunities to create common spaces for experience, action, and communication. The experience gained and the skills and competencies acquired are suitable for improving self-efficacy, self-confidence, and opportunities for participation in society” (Initiative “Keine Bildung ohne Medien”, 2011, p. 10).

- Competencies in the design of barrier-free teaching. That is realized in a barrier-free e-learning platform, barrier-free course, and material design and barrier-free university didactics. Students learn, for example, to create barrier-free digital documents and presentations, to use simple language and to use the technical support functions of the digital devices optionally by all pupils. The cooperation model of the two professorships currently includes various regular courses offered at least once per academic year.

- Universal design as a continuation of the approach of accessibility; barrier-free design with particular attention to usability. The approach attempts to design products or environments in such a way that they can be used by all people from the outset, without the need for adaptations or special design. It is a human-oriented design approach, making media accessible to as many people as possible, but it does not only apply to media. Universal design for learning attempts to avoid stigmatisation and exclusion from the outset (Wember, 2013). 
- During the university courses and the tutorials, they can acquire competences to take various aspects of disabilities and other aspects of heterogeneous classrooms into account. They get on overview as well as practical experiences in these four aspects of accessibility and inclusive media education:

1. Technical level

Alternative input methods/ assistive technologies

e.g., voice control, on-screen keyboard, screen reader, joystick

2. Level of representation

Adaptation of media for different output variants

e.g., magnification, adjustability of color and contrast, subtitles, audio description, sign language

3. Content level

Comprehensibility of the texts/complexity reduction

e.g., by easy-to-read or plain language

4. Social level

e.g., sufficient material and immaterial resources

During their Master studies, the students have the chance to acquire specializes knowledge, e.g., in inclusive radio production (Bosse, 2014a) or inclusive film work (Bosse, 2014b) (see Table 1):

Table 1

Overview of the Courses Within the Offered Teaching and Research Concept

\begin{tabular}{|c|c|c|}
\hline Study phase & Events & Responsibility \\
\hline BA-study & $\begin{array}{l}\text { Reading: Use of tablets for diagnosis and promotion for reading ability ( } 2 \\
\text { CP) (with a part of school practice) }\end{array}$ & German \\
\hline BA-study & Tutorial: Inclusive digital media education I (1 CP) & $\begin{array}{l}\text { Rehabilitation sciences } \\
\text { German }\end{array}$ \\
\hline BA-study & Tutorial: Inclusive digital media education II (1 CP) & $\begin{array}{l}\text { German } \\
\text { Rehabilitation sciences }\end{array}$ \\
\hline BA/MA-study & $\begin{array}{l}\text { Inclusive media education in educational and extracurricular contexts (2 CP) } \\
\text { (with school practice) }\end{array}$ & $\begin{array}{l}\text { Rehabilitation sciences } \\
\text { German }\end{array}$ \\
\hline MA-study & Inclusive school cinema weeks (3 CP) (with school practice) & Rehabilitation sciences \\
\hline MA-study & Radio work within the school (3 CP) (with school practice) & Rehabilitation sciences \\
\hline MA-study & $\begin{array}{l}\text { Media in inclusive specialized classes-didactic questions at the interface of } \\
\text { literature didactics and special education ( } 2 \mathrm{CP} \text { ) (with school practice) }\end{array}$ & $\begin{array}{l}\text { German } \\
\text { Rehabilitation sciences }\end{array}$ \\
\hline MA-study & $\begin{array}{l}\text { Digital learning in heterogeneous learning environments (2 CP) (with school } \\
\text { practice) }\end{array}$ & German \\
\hline
\end{tabular}

In the subject of German Literacy Didactics, all classes are also credible in the certificate study course Literature Pedagogy. Both the tutorials and the courses are included in the study regulations of both subjects and can be credited. In both the Bachelor's and Master's programmes, we teach one session in a team. For the accompanying research study, the question arises in how far the practical teaching experience itself is influencing the way students describe their attitude and confidence in the inclusive use of digital media (Marci-Boehncke \& Vogel, 2018).

\section{Results of the Accompanying Evaluation}

Within the framework of scientific assessment, we evaluated the German seminar participants in triangulated design (Treumann, 2017, pp. 265-266) with questionnaires at the beginning and end of the seminar about their self-assessed competencies in the technical and pedagogical handling of various digital media and the implementation of inclusive learning settings. They should also comment on their attitudes and previous 
experience of inclusion and digital work in teacher training. Additionally, we conducted in-depth interviews with selected students. Of further interest was the extent to which the interviewees could reflect on their learning gains, what role theory and practice play for them (Marci-Boehncke \& Trapp 2019; Trapp, 2019). The qualitative-empirical evaluation has not yet been completed, but it is already becoming clear:

The data from two semesters show that the participants remained highly reliable. These are mainly students who already have a positive attitude towards inclusion and digital media education. With differences between school types and also gender-specific differences, the measures have improved competence assessments on the technical and conducted didactic use of media as well as diagnostic and promotion-related reading skills. It becomes clear that students of special education have a more differentiated understanding of inclusion, but do not rate their skills in using digital media in the context of inclusion higher than other students. Through the seminar, the students changed their initially often slightly negative or maybe just ignorant attitude towards digital media. In the beginning, this female student seems to be rather traditionally orientated towards media:

...where it's just about visualization, where it's always about letting your own imagination play, creating images and links yourself, I think it doesn't make sense (using digital media, GMB). Well, I would do that now, if I wanted to represent a parabola, then I would do that with the chalk or just intuitively let students represent how they would have it drawn. There will be a change from the motor to the cognitive, I think that (working with digital media for children with a need for support, GMB) would be a hindrance. (Trapp, 2019, p. 292) (translation GMB)

At the end of the course she argues differently:

So in any case in the field of text comprehension (...) of course, I find that you can also make such small projects out of it within the framework of digital media. That you say, for example, that we now have the topic "forest" and (...) everyone looks if he finds something on the Internet (...) ...that they also work totally independently...and if you find something there that interests you (...) then you can google (...) and even if you say later, (...) work with Powerpoint (...) these are all things that are now so standard. (...) These are things you have to be able to do. (Trapp, 2019, p. 396) (translation GMB)

The fact that the theoretical background is decisive here is also confirmed by the result that students with a higher affinity to media who have already attended several events from the certificate "Literature Pedagogics" (Marci-Boehncke, 2016, pp. 80-81), in which the concept of mediatization is repeatedly presented and included in the work, respond more positively already in the beginning of the courses.

Yes, this individual work is much easier with media (...). For example, if you work with tablets and then work on the respective stand, then even particularly strong students can continue to do the tasks and so can the weaker students. And I think, especially when it comes to bilingualism (...), it is also a very good possibility if you can link languages with each other in the media. If, for example, one now also thinks that there are picture books in digital media that are pronounced in one's mother tongue and then (...) are heard in German and in one's mother tongue (...) or vice versa, this definitely offers potential in these areas. (Trapp, 2019, p. 279) (translation GMB)

The results show that students do value such seminars, but these classes also mean an increased effort, which not many teacher-training students (so far) can or want to provide. Besides, student courses/tutorials enabled a deepening of practical media skills through exercises with various applications (film and radio play production, comic production, quiz, and other special-App creation) as well as first insights into the use of assistive technologies. 


\section{Conclusion}

When choosing a course of study, students already bring with them preconceived attitudes to professional understanding - not least from their own school experience-that can prove to be very stable over time (Denzler \& Wolter, 2008; Neugebauer, 2013; Košinár, 2014). As a result, they can manifest themselves in a limited understanding of the profession through failing practical experience. The strengthening experiences in practice, which help to deepen the self-efficacy also in the areas of inclusion and digital media action, need in our opinion a background knowledge which is theory-based and allows to reflect critically on experiences and requirements and thus to transfer them into one's teaching behavior. This background knowledge, which Shulman (1986) also demanded from teachers as part of their professional knowledge (Baumert \& Kunter, 2006, p. 482) -both as specialist knowledge and as "educational philosophical, educational theoretical and historical knowledge"-in our view remains a necessary prerequisite for sustainable practice. University education has the task of examining and teaching new theories for relevance in teacher training. The changes that these theories mean for school practice are varied and range from selective changes in textbook chapters to fundamental new teaching and working materials and new mediation strategies.

Concerning inclusion and mediatization, the interdisciplinary study model of German Literacy Didactics and Rehabilitation Sciences for digital media education in inclusive (German) teaching in several seminars of both study phases provided both theoretical knowledge and practical application possibilities for teachers of all teaching positions. By scientific and scientific didactic planning, the students were able to carry out their teaching experiments in various school types and then reflect in the seminar context together with fellow students as well as with the team of lecturers from both areas. The differentiation and use of digital media were carried out following the recommendations of "Universal Design for Learning” (Wember, 2013). The media were understood not only as a technical aid but also as a learning object. The TPACK Model also serves to plan and train new aspects of competence in training.

The Global Education Monitoring Report of UNESCO 2020 will focus on inclusion and, among other things, "investigate how to improve cooperation between special needs and mainstream teachers, as well as between teachers and support personnel, to ensure inclusive practice” (UNESCO, 2018, p. 6). It will also be essential to understanding how different training practices influence the degree of preparedness and to what extent the "Universal Design for Learning" concept is implemented. Of particular, interest here will be where Germany, as one of the countries in the process of transformation from a segregative to an inclusive school system, stands in comparison to states in a comparable stage. Further research should be realized with an international consortium with other partners in the world in order to have comparative factorial analysis.

\section{References}

Abels, S., \& Schütz, S. (2016). Fachdidaktik trifft inklusive Pädagogik-(Unausgeschöpfte) Potentiale in der Lehrerbildung. Zeitschrift für Heilpädagogik, 67(9), 425-436.

Baumert, J., \& Kunter, M. (2006). Stichwort: Professionelle Kompetenz von Lehrkräften. Zeitschrift für Erziehungswissenschaft, 9(4), 469-520.

Bešić, E., Paleczek, L., Krammer, M., \& Gasteiger-Klicpera, B. (2017). Inclusive practices at the teacher and class level: The

experts' view. European Journal of Special Needs Education, 32(3), 329-345. Retrieved from https://doi.org/10.1080/08856257.2016.1240339

Biermann, R. (2009). Der digitale Habitus von Lehramtsstudierenden. Eine quantitative Studie zum Medienverhalten angehender Lehrpersonen. Wiesbaden: VS Verlag für Sozialwissenschaften. 
Bos, W., Eickelmann, B., Gerick, J., Goldhammer, F., Schaumburg, H., \& Schwippert, K. (Hg.) (2014). ICILS 2013. Computer-und informationsbezogene Kompetenzen von Schülerinnen und Schülern in der 8. Jahrgangsstufe im internationalen Vergleich. Münster, Westf: Waxmann.

Bos, W., Lorenz, R., Endberg, M., Eickelmann, B., Kammerl, R., \& Welling, S. (Eds.) (2016). Schule digital-der Länderindikator 2016. Kompetenzen von Lehrpersonen der Sekundarstufe I im Umgang mit digitalen Medien im Bundesländervergleich. Münster, New York: Waxmann.

Bosse, I. (2018). Basiswissen zur Mediennutzung von Menschen mit Behinderungen und seine Implikationen für die inklusive Didaktik im Fach Deutsch. In P. Anders and P. Wieler (Eds.), Literalität und Partizipation. Reden, Schreiben, Gestalten in und zu Medien (pp. 83-102). Tübingen: Stauffenburg.

Bosse, I. (2014a). Radioarbeit. Ein Ansatz für inklusive Medienbildung in der Schule. Computer + Unterricht, 94, 29-31.

Bosse, I. (2014b). Inklusive Schulkinowochen NRW. In S. Schuppener, N. Bernhardt, M. Hause, and F. Poppe (Eds.), Inklusion und Chancengleichheit. Diversity im Spiegel von Bildung und Didaktik (pp. 320-325). Bad Heilbrunn: Klinkhardt.

Bronfenbrenner, U. (1979). The ecology of human development: Experiments by nature and design. Cambridge, MA: Harvard University Press.

Brüggemann, M., Welling, S., \& Breiter, A. (2014). Gelingende Inklusion mit Medienintegration. Einblicke in relevante Aspekte der Schulentwicklung. Computer + Unterricht, 94, 6-9.

Christensen, C. M. (1997). The innovator's dilemma: When new technologies cause great firms to fail. Boston, MA: Harvard Business School Press.

Denzler, S., \& Wolter, S. C. (2008). Selbstselektion bei der Wahl eines Lehramtsstudiums—zum Zusammenspiel individueller und institutioneller Faktoren. Beiträge zur Hochschulforschung, 30(4), 112-141. Retrieved from http://www.bzh.bayern.de/uploads/media/4-2008-denzler-wolter.pdf

European Agency for Special Needs and Inclusive Education. (2018). Country information for Germany-Legislation and policy. Retrieved from https://www.european-agency.org/country-information/germany/legislation-and-policy

Frau-Meigs, D., Velez, I., \& Flores Michel, J. (2017). Public policies in media and information literacy in Europe. London: Taylor and Francis.

Initiative “Keine Bildung ohne Medien” (Ed.) (2011). Bildungspolitische Forderungen. Medienpädagogischer Kongress 2011. Retrieved

from http://www.keine-bildung-ohne-medien.de/kongress-dokumentation/keine-bildung-ohne-medien_bildungspolitische-forderun gen.pdf

Jenkins, H., \& Kelley, W. (Eds.) (2013). Reading in a participatory culture: Remixing Moby-Dick in the English classroom. New York: Teachers College Press.

Johnson, M. (2015). Co-teaching: Voraussetzung und Garant für eine Schule für Alle-Erfahrungen aus den USA. Retrieved from http://www.inklusion-online.net/index.php/inklusion-online/article/view/262/248

Kallmeyer, W., Klein, W., \& Meyer-Hermann, R. (1974). Lektürekolleg zur Textlinguistik, Band 1: Einführung. Königstein/Ts.: Athenäum.

Koehler, M. J., \& Mishra, P. (2005). What happens when teachers design educational technology? The development of technical pedagogical content knowledge. Journal of Educational Computing Research, 32(2), 131-152.

Köller, O., Baumert, J., \& Neubrand, J. (2000). Epistemologische Überzeugungen und Fachverständnis im Mathematik-und Physikunterricht. In J. Baumert, W. Bos, and R. Lehmann (Eds.), TIMSS/III. Dritte Internationale Mathematik-und Naturwissenschaftsstudie-Mathematische und naturwissenschaftliche Bildung am Ende der Schullaufbahn (Band 2: Mathematische und physikalische Kompetenzen am Ende der gymnasialen Oberstufe) (pp. 229-270). Opladen: Leske + Budrich.

Kontovourki, S., Garoufallou, E., Ivarsson, L., Klein, M., Korkeamaki, R. L., Koutsomiha, D., Marci-Boehncke, G., Tafa, E., \& Virkus, S. (2017). Digital literacy in the early years: Practices in formal settings, teacher education, and the role of informal learning spaces: A review of the literature. COST ACTION IS1410. Retrieved from http://digilitey.eu/wp-content/uploads/2017/01/WG2-LR-March-2017-v2.pdf

Košinár, J. (2014). Die Bedeutung von Passungserfahrungen für Professionalisierungsverläufe im Referendariat. ZISU, 3, $29-43$.

Krotz, F. (2007). Mediatisierung. Fallstudien zum Wandel von Kommunikation. Wiesbaden: VS Verlag für Sozialwissenschaften.

Krotz, F. (2009). Mediatization: A concept with which to grasp media and societal change. In K. Lundby (Ed.), Mediatization: Concept, changes, consequences (pp. 21-40). Frankfurt/Main, New York, Oxford: Peter Lang. 
Kronauer, M. (2013). Soziologische Anmerkungen zu zwei Debatten über Inklusion und Exklusion. Bielefeld: W. Bertelsmann Verlag. Retrieved from https://www.ssoar.info/ssoar/handle/document/36929

Lütje-Klose, B. (2011). Inklusion. Welche Rolle kann die Sonderpädagogik übernehmen? Sonderpädagogische Förderung in NRW, 8, 21.

Lorenz, R., Endberg, M., \& Eickelmann, B. (2017). Unterrichtliche Nutzung digitaler Medien durch Lehrpersonen in der Sekundarstufe I im Bundesländervergleich und im Trend von 2015 bis 2017. In R. Lorenz et al. (Eds.), Schule digital-der Länderindikator 2017. Schulische Medienbildung in der Sekundarstufe I mit besonderem Fokus auf MINT-Fächer im Bundesländervergleich und Trends von 2015 bis 2017 (pp. 84-128). Münster, New York: Waxmann.

Marci-Boehncke, G. (2016). Leseförderung 3.0.-eine Bilanz zum veränderten Bewusstsein der “Experten für das Lesen”. ProLibris, 2, 79-81.

Marci-Boehncke, G. (2018). Von der integrierten zur inklusiven Medienbildung. In T. Hug (Ed.), Medienpädagogik. Herausforderungen für Lernen und Bildung im Medienzeitalter (pp. 49-64). Innsbruck: Innsbruck University Press.

Marci-Boehncke, G., \& Bosse, I. (2018). Inklusive digitale Medienbildung im (Deutsch-)Unterricht: Ein kooperatives Lehrkonzept von Rehabilitationswissenschaften und Literaturdidaktik. In S. Hußmann \& B. Welzel (Eds.), Dortmunder Profil für inklusionsorientierte Lehrerinnen- und Lehrerbildung (pp. 222-235). Münster: Waxmann.

Marci-Boehncke, G., \& Vogel, T. (2018). Digital literacy and inclusion: The impact of theory and practice in teachers' education. The 12th International Technology, Education and Development Conference, 5-7 March, Valencia, Spain.

Marci-Boehncke, G., \& Trapp, R. (2019). Digital literacy in primary school education-A question of belief and epistemological awareness: Results from the DoProfiL-study about students theoretical and practical knowledge and beliefs towards inclusive media education. Medienimpulse. Retrieved May 20, from https://journals.univie.ac.at/index.php/mp/article/view/mi1317/1441

Mar Grandío, M., Dilli, S., \& O’Neill, B. (2017). Legal frameworks for media and information literacy. In D. Frau-Meigs, I. Velez, and J. Flores Michel (Eds.), Public policies in media and information literacy in Europe (Routledge studies in European communication research and education (pp.116-129). London: Taylor and Francis.

McGarr, O., \& McDonagh, A. (2019). Digital competence in teacher education, output 1 of the Erasmus+ funded developing student teachers' digital competence (DICTE) project. Retrieved May 25, 2019, from https://dicte.oslomet.no/

Moser, V., \& Demmer-Dieckmann, I. (2012). Professionalisierung und Ausbildung von Lehrkräften für inklusive Schulen. In Moser (Ed.), Die inklusive Schule (pp. 155-176). Stuttgart: Kohlhammer.

Neugebauer, M. (2013). Wer entscheidet sich für ein Lehramtsstudium und warum? Eine empirische Überprüfung der These von der Negativselektion in den Lehrerberuf. Zeitschrift für Erziehungswissenschaft, 16, 157-184.

Rath, M. (2014). Ethik der mediatisierten Welt. Grundlagen und Perspektiven. Wiesbaden: VS Verlag für Sozialwissenschaften.

Richter, D., \& Pant, H. A. (2016). Lehrerkooperationen in Deutschland. Eine Studie zu kooperativen Arbeitsbeziehungen bei Lehrkräften der Sekundarstufe I. Gütersloh, Stuttgart, Essen, Bonn: Bertelsmann Stiftung, Robert Bosch Stiftung, Mercator, Deutsche Telekom Stiftung. Retrieved from https://www.bertelsmann-stiftung.de/de/publikationen/publikation/did/lehrerkooperation-in-deutschland/

Shulman, L. S. (1986). Those who understand: Knowledge growth in teaching. Educational Researcher, 15(2), 4-14.

Scherer, R., Tondeur, J., \& Siddiq, F. (2017). On the quest for validity: Testing the factor structure and measurement invariance of the technology-dimensions in the technological, pedagogical, and content knowledge (TPACK) model. Computers \& Education, 112, 1-17.

Schmid, U., Goertz, L., \& Behrens, J. (2017a). Monitor Digitale Bildung. Die Schulen im digitalen Zeitalter. Gütersloh: Bertelsmann Stiftung. $\quad$ Retrieved December 29, 2018, from https://www.bertelsmann-stiftung.de/en/publications/publication/did/monitor-digitale-bildung-9/

Schmid, U., Goertz, L., Radomski, S., Thom, S., \& Behrens, J. (2017b). Monitor Digitale Bildung. Die Hochschulen im digitalen Zeitalter. Gütersloh: Bertelsmann $\quad$ Stiftung. https://www.bertelsmann-stiftung.de//de/publikationen/publikation/did/monitor-digitale-bildung-2/

Thiele, A. (2016). Assistive Technologien für Menschen mit einer körperlich-motorischen Beeinträchtigung. Interdisziplinäre Handlungsfelder und Eckpfeiler einer Qualifikation von Pädagog/innen mit einem sonderpädagogischen Profil. Vierteljahresschrift für Heilpädagogik und ihre Nachbargebiete, 85, 307-322.

Thiele, A., \& Bosse, I. (2019). Inklusionsorientierter Literaturunterricht mit (digitalen) Medien. Ein Beispiel für die Auseinandersetzung der Fachdidaktiken mit Inklusion in einer mediatisierten Gesellschaft. In I. Bosse, J. R. Schluchter, and I. Zorn (Hrsg.), Handbuch Inklusion und Medienbildung (pp. 77-93). Weinheim: Beltz/Juventa. 
Thom, S., Behrens, J., Schmid, U., \& Goertz, L. (2017). Monitor Digitale Bildung. Digitales Lernen an Grundschulen. Gütersloh: Bertelsmann Stiftung. Retrieved from https://www.bertelsmann-stiftung.de/index.php?id=5772\&tx_rsmbstpublications_pi2\%5bdoi\%5d=10.11586/2017040

Trapp, R. (2019). Beliefs von Lehramtsstudierenden zu digitalen Medien im inklusiven Deutschunterricht. Eine empirische Studie aus fachdidaktischer Perspektive (Dissertation, University of Dortmund).

Treumann, K. (2017). Triangulation. In M. Wegener (Ed.), Qualitative Medienforschung (pp. 264-275). München: UVK Verlagsgesellschaft mbH.

United Nations (UN). (Ed.). (2006). Conventions on the rights of persons with disabilities and optional protocol. New York: UN.

United Nations Educational, Scientific and Cultural Organization (UNESCO). (2009). Policy guidelines on inclusion in education. Retrieved from http://unesdoc.unesco.org/images/0017/001778/177849e.pdf

UNESCO. (2017). Media and information literacy. Retrieved from http://www.unesco.org/new/en/communication-and-information/media-development/media-literacy/mil-as-composite-conce $\mathrm{pt} / \mathrm{browse} / 4 /$

UNESCO. (2018). Concept note-2020 global education monitoring report. Retrieved from http://www.unesco.org/gemreport

Villa, R. A., Thousand, J. S., \& Nevin, A. I. (2004). A guide to co-teaching: Practical tips for facilitating student learning. London: SAGE Publications.

Wember, F. B. (2013). Herausforderung Inklusion: Ein präventiv orientiertes Modell schulischen Lernens und vier zentrale Bedingungen inklusiver Unterrichtsentwicklung. Zeitschrift für Heilpädagogik, 64(10), 380-387.

Zorn, I., Schluchter, J. R., \& Bosse, I. (2019). Handbuch Inklusion und Medienbildung. Weinheim: Beltz Juventa. 